\title{
PENGEMBANGAN MODEL PEMBELAJARAN MATEMATIKA DENGAN MEMANFAATKAN SISTEM SOSIAL MASYARAKAT
}

\author{
Usman Mulbar \\ FMIPA Universitas Negeri Makassar \\ email: u_mulbar@yahoo.com
}

\begin{abstract}
Abstrak: Penelitian pengembangan ini bertujuan untuk menghasilkan model pembelajaran matematika yang memanfaatkan sistem sosial masyarakat. Populasi penelitian adalah siswa kelas VII SMP Negeri di Provinsi Sulawesi Selatan, sedang sampel dipilih secara purposive random sampling sebanyak 12 (dua belas) kelas dari 6 kabupaten/kota. Data dianalisis melalui perpaduan deskriptif dan kualitatif. Produk yang dihasilkan berupa buku model pembelajaran dan perangkat pendukung pembelajaran, adalah rencana pelaksanaan pembelajaran, buku siswa, lembar kegiatan siswa, dan tes hasil belajar. Hasil yang diperoleh menunjukkan bahwa (1) dalam proses pengujian awal (validasi) terlihat bahwa model pembelajaran dapat dinyatakan valid ditinjau dari keseluruhan komponen; (2) secara teoretis model pembelajaran dinyatakan layak diterapkan di kelas dan secara empiris; model pembelajaran ini dinyatakan memenuhi kriteria praktis dan efektif sehingga dapat digunakan di sekolah.
\end{abstract}

Kata Kunci: model pembelajaran matematika, sistem sosial masyarakat

\section{DEVELOPING MATHEMATICS LEARNING MODELS UTILIZING THE COMMUNITY SOCIAL SYSTEM}

\begin{abstract}
This developmental research aimed at producing a model of mathematics instruction utilizing the community social system. The research population was Grade VII students of State Junior Secondary Schools in South Sulawesi Province from which 12 classes in 6 disctricts were drawn as the research sample using the purposive random sampling technique. The data were analyzed using the descriptive qualitative analysis. The yielded products included the book of the instructional model and the supporting package for the instruction, namely, lesson plans, student books, student worksheets, and achievement tests. The research findings were: (1) the validation processes covering all aspect/components revealed that the model was valid; (2) theoretically, the instructional model was considered feasible to be applied in the classroom setting; while empirically, the model satisfied the criteria of being practical and effective, and it, therefore, could be implemented at schools.
\end{abstract}

Keywords: model of mathematics instruction, community social system

\section{PENDAHULUAN}

Matematika merupakan ilmu universal yang mendasari perkembangan teknologi modern dan mempunyai peran penting dalam berbagai disiplin ilmu serta memajukan daya pikir manusia. Perkembangan pesat pada bidang teknologi informasi dan komunikasi dilandasi oleh perkembangan matematika pada bidang teori bilangan, aljabar, analisis, teori peluang, dan matematika diskrit. Karena itu, untuk menguasai dan memanfaatkan teknologi di masa depan diperlukan penguasaan matematika yang kuat sejak dini.
Menyadari pentingnya penguasaan matematika, maka dalam Undang-Undang RI No. 20 Tahun 2003 tentang Sisdiknas (Sistem Pendidikan Nasional) Pasal 37 ditegaskan bahwa mata pelajaran matematika merupakan salah satu mata pelajaran wajib bagi siswa di jenjang pendidikan dasar dan menengah. Sejalan dengan UndangUndang tersebut, Soedjadi (2000:45) menyatakan bahwa wujud dari mata pelajaran matematika di pendidikan dasar dan menengah adalah matematika sekolah. Matematika sekolah adalah unsurunsur atau bagian-bagian dari matematika yang dipilih berdasarkan atau berorientasi kepada ke- 
pentingan pendidikan dan kepentingan untuk menguasai dan memanfaatkan teknologi di masa depan. Karena itu, mata pelajaran matematika yang diberikan di pendidikan dasar dan menengah juga dimaksudkan untuk membekali siswa dengan kemampuan berpikir logis, analitis, sistematis, kritis, dan kreatif, serta kemampuan bekerjasama. Kemampuan tersebut, merupakan kompetensi yang diperlukan oleh siswa agar dapat memiliki kemampuan memperoleh, mengelola, dan memanfaatkan informasi untuk bertahan hidup pada keadaan yang selalu berubah, tidak pasti, dan kompetitif.

Salah satu upaya untuk mencapai kompetensi yang diperlukan oleh siswa dalam pembelajaran matematika adalah penerapan model pembelajaran yang memanfaatkan sistem sosial masyarakat. Model pembelajaran tersebut dipandang penting karena pemanfaatan sistem sosial masyarakat dalam pembelajaran matematika dapat menstimulus fungsi mental yang lebih tinggi bagi peserta didik. Mengingat fungsi mental yang lebih tinggi mengandung unsur sosial yang dapat dicapai melalui interaksi sosial yang melibatkan fakta dan simbol-simbol. Fakta dan simbol-simbol yang bersumber dari pemanfaatan sistem sosial masyarakat mempengaruhi perkembangan pemahaman individu. Oleh karena itu, diperlukan suatu alternatif model pembelajaran matematika agar penguasaan siswa terhadap kompetensi matematika yang diharapkan dapat terpenuhi.

Penerapan pendekatan model pembelajaran seperti di atas, tampak sejalan dengan paham konstruktivis. Konstruktivistik memandang pengetahuan matematika adalah hasil konstruksi pikiran manusia dan dalam pembentukannya melibatkan aktivitas aktif siswa. Karena pembentukan pengetahuan dengan melibatkan pemahaman dan pengalaman belajar siswa, baik dari hasil interaksi dan skemata yang telah dimiliki sebelumnya. Namun demikian, interaksi konstruktif antar siswa dengan temannya, siswa dan guru, siswamasalah-guru sangat sulit dikondisikan. Permasalahan tersebut, juga terjadi di awal penerapan paradigma pembelajaran konstruktivis dalam pembelajaran matematika di Amerika Serikat. Davis (1990:2) menyatakan bahwa terdapat tiga hal penyebab kegagalan paradigma pembelajaran konstruktivis, yaitu: (1) harapan tradisional yang berbeda jauh dari tujuan dan metode programprogram konstruktivis; (2) kurangnya pemahaman guru terhadap pendekatan konstruktivis; dan (3) umumnya siswa berpikir bahwa matematika hanya menunjuk ke aritmetika hafalan tanpa arti, dan ia tidak dapat melihat matematika sebagai mata pelajaran yang memungkinkan untuk memahami apa yang mereka lakukan, serta mata pelajaran yang cocok untuk proses berpikir kreatif.

Djamarah (2000:23) menyatakan bahwa interaksi pembelajaran yang bersumber dari sistem sosial masyarakat dapat diubah menjadi interaksi yang bernilai edukatif. Kebiasaan siswa yang secara pasif menerima ilmu pengetahuan, dan kebiasaan guru yang terlalu mendominasi siswa dalam pembelajaran yang sangat tidak relevan dengan tuntutan pembelajaran matematika ke depan, dapat diubah melalui pola interaksi sistem sosial masyarakat. Misalnya, nilai didikan leluhur yang pada intinya membelajarkan siswa mandiri, bermusyawarah dalam memecahkan masalah, saling berbagi pengetahuan antara siswa yang pintar dan yang lemah, dan melibatkan fakta dan simbol budaya.

Berdasarkan uraian yang dikemukakan di atas, perlu dilakukan penyempurnaan suatu model pembelajaran, baik dalam hal kegiatan pembelajaran, aktivitas siswa, maupun komponen lain yang harus dimiliki dalam pembelajaran. Selanjutnya, disajikan beberapa pertimbangan dalam pengembangan model pembelajaran matematika yang memanfaatkan sistem sosial masyarakat, yaitu sebagai berikut. (1) Rekonstruksi konsep, permasalahan yang diajukan berkaitan dengan kehidupan nyata dan pengalaman siswa, serta bersumber dari fakta \& lingkungan sosial masyarakat. (2) Pengorganisasian siswa dalam pembelajaran matematika yang memanfaatkan sistem sosial masyarakat diharapkan sesuai dengan kondisi lingkungan dimana siswa berada. (3) Pengalaman sebelumnya ikut menentukan makna informasi yang diterima oleh siswa. Setiap siswa mencoba menginterpretasi informasi yang diterimanya berdasarkan pengalaman sebelumnya atau pengetahuan yang dimiliki (pre-knowledge). Pengalaman-pengalaman sosial ikut terbawa ke 
dalam ruang kelas, ketika siswa belajar matematika. (4) Model pembelajaran matematika yang memanfaatkan sistem sosial masyarakat bertujuan untuk menjembatani perkembangan fungsi mental siswa yang berangkat dari bidang sosial menuju bidang individual.

Demikian juga dalam proses pembelajaran, perangkat pembelajaran dapat memaksimalkan pengetahuan horizontal siswa, yaitu perpaduan pengetahuan dari hasil interaksi sosial dengan pengetahuan yang dimiliki siswa sebelumnya.

\section{METODE}

Jenis penelitian adalah Research \& Developmental $(R \& D)$ yang bertujuan untuk menghasilkan model pembelajaran matematika yang memanfaatkan sistem sosial masyarakat. Prosedur pengembangan menggunakan langkahlangkah sebagi berikut. (1) Tahap perancangan pendidikan dari Plomp (2007:9), yaitu investigasi awal, perancangan, realisasi, pengujian/evaluasi/ revisi, dan implementasi. (2) Unsur-unsur pengembangan pembelajaran dari Joyce \& Calhoun (2004:58), yaitu sintaks, prinsip reaksi, sistem sosial, sistem pendukung, dan dampak instruksional \&dampak pengiring. (3) Kualitas material (produk) pembelajaran dari Nieveen (1999: 27128), yaitu validitas, praktis, dan efektif. (4) Pengembangan sistem instruksional pembelajaran dari Dick \& Carey (2005:3), yaitu kriteria menyusun perangkat pembelajaran sebagai pendukung model (RPP, Buku Siswa, Buku Guru, LKS, dan Asesmen pembelajaran).

Subjek penelitian adalah siswa kelas VII SMPN di Provinsi Sulawesi Selatan. Instrumen yang digunakan dikembangkan melalui Focus Group Discussion (FGD). Peserta FGD adalah Dosen dan Guru/Instruktur matematika di SMP yang dipandang memiliki keahlian dalam bidang yang akan diteliti. Pelaksanaan FGD dilakukan dengan memberikan lembar penilaian kelayakan instrumen kepada setiap peserta, selanjutnya dilakukan diskusi/pembahasan hasil FGD. Instrumen yang dimaksud, yaitu (1) lembar observasi (pengamatan) keterlaksanaan model; (2) lembar observasi kemampuan guru mengelola pembelajaran; (3) lembar observasi ak- tivitas siswa dalam pembelajaran; (4) angket respon siswa terhadap pelaksanaan pembelajaran; dan (5) tes kompetensi hasil belajar siswa.

Data yang dibutuhkan dalam penelitian ini berupa data kuantitatif dan kualitatif. Data kuantitatif adalah keterlaksanaan model, kemampuan guru mengelola pembelajaran, aktivitas siswa dalam pembelajaran, respon siswa terhadap pelaksanaan pembelajaran, dan kompetensi hasil belajar. Selanjutnya data kualitatif adalah hasil wawancara guru dan siswa terhadap keterlaksanaan pembelajaran, aktivitas siswa dan respon siswa terhadap pelaksanaan pembelajaran. Data tersebut kemudian dianalisis untuk menentukan valid, praktis, dan efektifnya model pembelajaran yang dikembangkan.

Kriteria validitas model menggunakan pengkategorian kualitas pembelajaran yang diadaptasi dari Bloom, Madaus \& Hasting (1981: 643-649) untuk menentukan tingkat validitas model yang dikembangkan, yaitu:

$$
\begin{aligned}
\mathrm{V}<1,5 & \text { berarti tidak valid } \\
1,5 \leq \mathrm{V}<2,5 & \text { berarti kurang valid } \\
2,5 \leq \mathrm{V}<3,5 & \text { berarti cukup valid } \\
3,5 \leq \mathrm{V}<4,5 & \text { berarti valid } \\
4,5 \leq \mathrm{V} & \text { berarti sangat valid }
\end{aligned}
$$

Keterangan: $\mathrm{V}$ adalah validitas model pembikar.

Kriteria yang digunakan untuk memutuskan bahwa model memiliki derajat validitas yang memadai adalah (1) nilai $\mathrm{V}$ untuk keseluruhan aspek minimal berada dalam kategori cukup valid, dan (2) nilai V untuk aspek teoriteori pendukung, sistem sosial dan prinsip reaksi minimal berada dalam kategori valid. Apabila tidak demikian, maka perlu dilakukan revisi berdasarkan saran validator atau dengan melihat kembali aspek-aspek yang nilainya kurang.

Kriteria keterlaksanaan model menggunakan pengkategorian kualitas pembelajaran yang diadaptasi dari Bloom, Madaus \& Hasting (1981: 643-649) untuk menentukan tingkat keterlaksanaan model pembelajaran yang dikembangkan, yaitu:

$\mathrm{T}<1,5 \quad$ berarti tidak ada yang terlaksana 
$1,5 \leq \mathrm{T}<2,5$ berarti sebagian kecil saja yang terlaksana

$2,5 \leq \mathrm{T}<3,5$ berarti sekitar separuh terlaksana

$3,5 \leq \mathrm{T}<4,5 \quad$ berarti sebagian besar yang terlaksana

$4,5 \leq \mathrm{T}$ berarti seluruhnya terlaksana.

Kriteria yang digunakan untuk memutuskan bahwa model pembelajaran memiliki derajat keterlaksanaan adalah nilai $\mathrm{T}$ minimal berada dalam kategori sebagaian besar terlaksana atau seluruhnya terlaksana. Apabila nilai $\mathrm{T}$ berada di dalam kategori lainnya, maka perlu dilakukan revisi dengan melihat kembali aspek-aspek yang nilainya kurang.

Analisis data kemampuan guru dalam mengelola pembelajaran dilakukan dengan mencari nilai kategori dari beberapa aspek penilaian yang diberikan berdasarkan rencana pelaksanaan pembelajaran. Langkah-langkah yang digunakan untuk menentukan kemampuan guru dalam mengelola pembelajaran adalah: (1) melakukan rekapitulasi data, yaitu skor hasil penilaian pengamat kedalam setiap aspek yang dinilai; (2) menentukan nilai rata-rata, yaitu skor hasil penilaian pengamat untuk setiap aspek yang dinilai. Nilai tersebut merupakan nilai Kemampuan Guru (KG). Selanjutnya nilai (KG) dirujuk pada interval kriteria kualitas pembelajaran yang diadaptasi dari Bloom, Madaus \& Hasting (1981: 643-649) untuk menentukan tingkat kemampuan guru dalam mengelola pembelajaran, yaitu:

$\begin{array}{ll}4,5<\mathrm{KG} \leq 5 & \text { sangat baik } \\ 3,5 \leq \mathrm{KG} \leq 4,5 & \text { baik } \\ 2,5<\mathrm{KG} \leq 3,5 & \text { cukup baik } \\ 1,5<\mathrm{KG} \leq 2,5 & \text { kurang baik } \\ \mathrm{KG} \leq 1,5 & \text { tidak baik }\end{array}$

Keterangan: KG adalah nilai kemampuan guru.

Kriteria kemampuan guru, apabila setiap aspek yang dinilai tingkat pencapaian nilai kemampuan guru memenuhi kriteria minimal cukup baik. Apabila nilai kemampuan guru dalam mengelola pembelajaran untuk setiap pertemuan di bawah kriteria minimal cukup baik, maka peneliti melakukan peninjauan dengan merevisi perangkat atau memberi masukan pada guru untuk meningkatkan penguasaan dan keterampilan mengajarnya, khususnya pada bagian yang teramati belum memenuhi kriteria minimal cukup baik.

Analisis data aktivitas siswa selama kegiatan pembelajaran berlangsung dilakukan dengan cara mencari rata-rata frekuensi dan ratarata persentase waktu yang digunakan siswa dalam melakukan aktivitas selama kegiatan pembelajaran ditentukan melalui langkah-langkah: (1) hasil pengamatan aktivitas siswa untuk setiap indikator aktivitasnya dalam satu kali pertemuan kemudian ditentukan frekuensinya dan dicari rata-rata frekuensi. Selanjutnya ditentukan frekuensi rata-rata dari rata-rata frekuensi untuk beberapa kali pertemuan; (2) mencari persentase frekuensi setiap indikator dengan cara membagi besarnya frekuensi dengan jumlah frekuensi untuk semua indikator. Kemudian hasil pembagian dikalikan dengan $100 \%$. Selanjutnya dicari rata-rata persentase waktu untuk beberapa kali pertemuan dan dimasukkan dalam tabel rata-rata persentase. Kriteria aktivitas siswa dikatakan efektif, apabila untuk setiap pertemuan yaitu persentase frekuensi seluruh indikator aktivitas siswa dalam tugas (on-task) dan aktivitas siswa luar tugas (off-task) memenuhi batas kriteria waktu ideal yang telah ditetapkan di rencana pelaksanaan pembelajaran dengan toleransi sebesar 5\%. Apabila kriteria aktivitas siswa belum memenuhi kriteria efektif, maka peneliti melakukan peninjauan dengan merevisi model atau memberi masukan pada guru untuk memperhatikan aspek aktivitas siswa, khususnya pada indikator yang belum memenuhi kriteria waktu ideal yang telah ditetapkan.

Analisis data respon siswa dilakukan dengan menentukan banyaknya siswa yang memberi jawaban bernilai respon positif atau negatif untuk setiap kategori yang ditanyakan dalam angket. Respon positif artinya siswa merespon dalam kategori senang, baru, berminat, jelas, dan tertarik untuk setiap aspek yang direspon terhadap pelaksanaan pembelajaran, sedangkan respon negatif berarti sebaliknya. Kriteria untuk menyatakan bahwa respon siswa terhadap model pembelajaran adalah positif, apabila lebih dari $80 \%$ siswa yang 
menyatakan: (1) senang terhadap pelaksanaan pembelajaran; (2) kegiatan pembelajaran merupakan hal baru; (3) dapat memahami dengan jelas bahasa yang dipergunakan; (5) tertarik dengan penampilan/tulisan guru. Sedangkan komentar siswa yang bersifat konstruktif dipergunakan sebagai bahan pertimbangan untuk melakukan revisi terhadap model pembelajaran.

Analisis data tes kompetensi hasil belajar yang dimaksud adalah analisis ketuntasan belajar siswa secara klasikal. Ketuntasan belajar siswa diperoleh apabila minimal $85 \%$ dari seluruh siswa memperoleh ketuntasan belajar secara individu, artinya paling sedikit $85 \%$ siswa yang memperoleh skor minimal 65 untuk rentang skor $0-100$. Kriteria pengkategorian skor tes kompetensi hasil belajar, menggunakan aturan pengkategorian di sekolah tempat pelaksanaan penelitian yang mengacu pada KTSP (Depdiknas, 2006: 18).

\section{HASIL DAN PEMBAHASAN Desain Model Pembelajaran}

Model pembelajaran matematika yang memanfaatkan sistem sosial masyarakat diawali dengan kajian teoretis tentang teori-teori belajar sebagai teori pendukung model, kondisi faktual pembelajaran, dan kondisi siswa saat ini. Berdasarkan hasil kajian tersebut, diperoleh disain awal komponen model, yaitu sebagai berikut.

\section{Sintaks}

Sintaks model pembelajaran adalah sebagai berikut.

Fase I : Apersepsi sistem sosial masyarakat sebagai pengantar, serta menyampaikan tujuan pembelajaran dan memotivasi siswa.

Fase II : Representasi pembelajaran melalui pola interaksi sosial masyarakat.

Fase III : Pengorganisasian siswa kedalam kelompok.

Fase IV : Presentase dan pengembangan hasil kerja.

Fase V : Penemuan objek matematika disertai pengembangan skemata baru.

Fase VI : Refleksi hasil pembelajaran disertai penghargaan.

\section{Sistem Sosial}

Prinsip yang terkandung dalam pola interaksi sistem sosial masyarakat adalah bekerja sama menyelesaikan masalah antara siswa-siswa, guru-siswa, dan kelompok; kebebasan mengemukakan pendapat; kerja sama siswa-siswa, gurusiswa, antara kelompok bertahan lama selama pembelajaran. Oleh karena itu, interaksi sosio kultural dimaksudkan untuk menghasilkan pemecahan masalah yang disepakati bersama.

\section{Prinsip Reaksi}

Model dilandasi teori konstruktivis dan nilai sistem sosial masyarakat yang memberi penekanan pembelajaran berpusat pada aktivitas siswa sehingga guru berfungsi sebagai fasilitator, konsultan, dan mediator dalam pembelajaran. Karena itu, hal-hal yang perlu dilakukan guru adalah: (1) menciptakan suasana pembelajaran,seperti menguji pemahaman siswa melalui pemberian contoh dan non-contoh; (2) menyediakan sumber belajar yang memadai, seperti LKS dan soal-soal tugas; (3) mengarahkan siswa untuk selalu berada dalam tugas, seperti membimbing siswa mengorganisasikan tugastugas; (4) memberikan bantuan berupa scaffolding kepada individu/kelompok; dan (5) memberi umpan balik.

\section{Sistem Pendukung}

Agar model dapat terlaksana secara praktis dan efektif, guru diwajibkan membuat suatu rancangan pembelajaran disertai sistem pendukung lainnya, seperti rencana pelaksanaan pembelajaran, buku siswa, LKS, tes kompetensi hasil belajar, tugas-tugas individu/kelompok dan rubrik penilaian dan materi pendukung lainnya.

\section{Dampak Instruksional dan Pengiring}

Model ini memberi penekanan pada pembelajaran yang berorientasi pada aktivitas siswa menemukan konsep dan prinsip matematika melalui pemecahan masalah yang bersumber dari fakta dan lingkungan sistem sosial masyarakat. Karena itu, aktivitas siswa menggunakan pola interaksi edukatif bersumber dari sistem sosial masyarakat yang melekat pada diri siswa. Dengan demikian, dampak langsung penerapan 
model ini adalah memampukan siswa merekonstruksi konsep dan prinsip matematika melalui pemecahan masalah dan terbiasa memecahkan masalah kehidupan nyata di lingkungannya melalui kolaborasi dengan pola interaksi sistem sosial masyarakat. Pemahaman siswa terhadap objek matematika dibangun berdasarkan pengalaman sistem sosial dan pengalaman belajar yang telah dimiliki sebelumnya. Selain itu, siswa akan terbiasa menganalisis secara logis dan kritis. Selanjutnya, dampak pengiring yang akan terjadi dalam penerapan model ini adalah siswa menyadari betapa tingginya nilai didikan leluhurnya dan berguna untuk digunakan dalam kehidupan, sehingga dia tidak merasa terasing dari lingkungannya.

\section{Hasil Uji Kualitas Model}

Hasil uji kualitas model meliputi: hasil uji validitas, hasil uji kepraktisan, dan hasil uji keefektifan adalah sebagai berikut.

Pertama, validitas dan reliabilitas model/ instrumen disajikan pada Tabel 1. Hasil tersebut menunjukkan bahwa model dan instrumen memenuhi kriteria validitas dan reliabilitas. Selanjutnya hasil penilaian pakar (dosen) dan praktisi (guru/ instruktur) pendidikan terhadap keseluruhan aspek/komponen model dan instrumen menyimpulkan bahwa secara konseptual memenuhi kriteria praktis dan efektif untuk diterapkan. Namun demikian, terdapat validator yang menyarankan bahwa model pembelajaran ini harus tetap berdasarkan teori konstruktivisme tanpa mengabaikan teori behaviorisme, karena model pembelajaran ini dapat menjembatani kedua teori tersebut.

Kedua, Hasil uji kualitas (hasil uji praktis) model menunjukkan bahwa: (1) keterlaksanaan setiap komponen model sintaks, system sosial, dan sistem pendukung termasuk kategori terlaksana, sedang prinsip reaksi termasuk kategori terlaksana sebagian; (2) kemampuan guru mengelola pembelajaran untuk komponen sintaks adalah cukup baik, sedang komponen sistem sosial, prinsip reaksi, dan sistem pendukung adalah baik. Hasil ini menunjukkan bahwa model pembelajaran memenuhi kriteria praktis.

Ketiga, Hasil uji kualitas (hasil uji efektif) model, yaitu sebagai berikut. Pertama, komponen aktivitas menunjukkan bahwa (1) melakukan kegiatan pembelajaran, (42,54\%); (2) memperhatikan penjelasan guru $(9,21 \%)$; dan (3) menyelesaian soal secara individu $(8,49 \%)$. Persentase aktivitas siswa tersebut, menunjukkan bahwa aktivitas kegiatan pembelajaran yang paling dominan. Selain itu, aktivitas aktif siswa (aktivitas yang berkaitan dengan pembelajaran) terlaksana dengan baik. Kedua, respon siswa terhadap pelaksanaan pembelajaran menunjukkan bahwa (1) siswa senang terhadap: kegiatan pelaksanaan pembelajaran, LKS yang digunakan, suasana pembelajaran, dan cara guru mengajar; (2) siswa berminat mengikuti pembelajaran selanjutnya, memahami dengan jelas bahasa yang digunakan oleh guru di kelas; (3) siswa tertarik dengan penampilan (tulisan, ilustrasi/gambar dan letak gambar) yang terdapat pada LKS dan tertarik dengan penampilan/cara guru mengajar. Selain itu, siswa berpendapat bahwa pembelajaran ini merupakan hal baru, siswa memperlihatkan minat yang sangat tinggi untuk terlibat langsung secara aktif dalam pembelajaran. Ketiga, kompetensi hasil belajar matematika siswa menunjukkan bahwa: $87,5 \%$ siswa yang memperoleh skor 65 ke atas. Selain itu, terdapat: (1) $12,5 \%$ siswa yang memperoleh skor rendah (belum mencapai ketuntasan belajar); (2) $20 \%$ siswa yang memperoleh skor sedang; (3) 17,5\% siswa yang memperoleh skor baik; dan (4) 50\% siswa yang memperoleh skor sangat baik. Hasil ini menunjukkan bahwa aktivitas siswa, respon siswa terhadap pelaksanaan pembelajaran, dan kompetensi hasil belajar siswa memenuhi kriteria efektif.

\section{Revisi Model}

Berdasarkan hasil uji kualitas model, selanjutnya dilakukan revisi model seperti disajikan pada Tabel 2. 
Tabel 1. Hasil Validasi dan Reliabilitas Model dan Instrumen

\begin{tabular}{lccccc}
\hline \multirow{2}{*}{ Komponen yang divalidasi } & Validitas & \multicolumn{3}{c}{ Reliabilitas } & \multirow{2}{*}{ Simpulan } \\
\cline { 2 - 5 } & Indeks & Ket. & Indeks & Ket. & \\
\hline Model Pembelajaran & 0,79 & Valid & 0,70 & Reliabel & LDR \\
Lembar penilaian kepraktisan \& keefektifan & 0,89 & Valid & 0,80 & Reliabel & LD \\
model & 0,91 & Valid & 0,85 & Reliabel & LD \\
Lembar observasi keterlaksanaan model & 0,87 & Valid & 0,78 & Reliabel & LD \\
Lembar observasi kemampuan guru mengelola & 0,80 & Valid & 0,72 & Reliabel & LDR \\
pembelajaran & 0,90 & Valid & 0,75 & Reliabel & LD \\
Lembar observasi aktivitas siswa & 0,75 & Valid & 0,70 & Reliabel & LDR \\
Angket respon siswa terhadap pembelajaran & & & & \\
Tes kompetensi hasil belajar &
\end{tabular}

Keterangan: LD (Layak Digunakan); dan LDR (Layak Digunakan dengan Revisi)

Kedua, Hasil uji kualitas (hasil uji praktis) model menunjukkan bahwa: (1) keterlaksanaan setiap komponen model sintaks, system sosial, dan sistem pendukung termasuk kategori terlaksana, sedang prinsip reaksi termasuk kategori terlaksana sebagian; (2) kemampuan guru mengelola pembelajaran untuk komponen sintaks adalah cukup baik, sedang komponen sistem sosial, prinsip reaksi, dan sistem pendukung adalah baik. Hasil ini menunjukkan bahwa model pembelajaran memenuhi kriteria praktis.

Ketiga, Hasil uji kualitas (hasil uji efektif) model, yaitu sebagai berikut. Pertama, komponen aktivitas menunjukkan bahwa (1) melakukan kegiatan pembelajaran $(42,54 \%)$; (2) memperhatikan penjelasan guru $(9,21 \%)$; dan (3) menyelesaikan soal secara individu $(8,49 \%)$. Persentase aktivitas siswa tersebut, menunjukkan bahwa aktivitas kegiatan pembelajaran yang paling dominan. Selain itu, aktivitas aktif siswa (aktivitas yang berkaitan dengan pembelajaran) terlaksana dengan baik. Kedua, respon siswa terhadap pelaksanaan pembelajaran menunjukkan bahwa (1) siswa senang terhadap: kegiatan pelaksanaan pembelajaran, LKS yang digunakan, suasana pembelajaran, dan cara guru mengajar; (2) siswa berminat mengikuti pembelajaran selanjutnya, memahami dengan jelas bahasa yang digunakan oleh guru di kelas; (3) siswa tertarik dengan penampilan (tulisan, ilustrasi/gambar dan letak gambar) yang terdapat pada LKS dan tertarik dengan penampilan/cara guru mengajar. Selain itu, siswa berpendapat bahwa pembelajaran ini merupa- kan hal baru, siswa memperlihatkan minat yang sangat tinggi untuk terlibat langsung secara aktif dalam pembelajaran. Ketiga, kompetensi hasil belajar matematika siswa menunjukkan bahwa: $87,5 \%$ siswa yang memperoleh skor 65 ke atas. Selain itu, terdapat: (1) $12,5 \%$ siswa yang memperoleh skor rendah (belum mencapai ketuntasan belajar); (2) $20 \%$ siswa yang memperoleh skor sedang; (3) 17,5\% siswa yang memperoleh skor baik; dan (4) $50 \%$ siswa yang memperoleh skor sangat baik. Hasil ini menunjukkan bahwa aktivitas siswa, respon siswa terhadap pelaksanaan pembelajaran, dan kompetensi hasil belajar siswa memenuhi kriteria efektif.

\section{Revisi Model}

Berdasarkan hasil uji kualitas model, selanjutnya dilakukan revisi model seperti disajikan pada Tabel 2.

\section{Penerapan Model Pembelajaran}

Penerapan model pembelajaran yang dimaksud adalah penerapan komponen model, yaitu penerapan sintaks, penerapan sistem sosial, dan penerapan prinsip reaksi.

\section{Penerapan Sintaks}

Penerampan sintaks pembelajaran adalah kegiatan yang diharapkan dilakukan oleh guru dan siswa untuk setiap fase pembelajaran. 
Tabel 2. Revisi Komponen Sintaks dan Sistem Sosial Model

\begin{tabular}{|c|c|c|c|}
\hline Disain Sintaks & Revisi Sintaks & $\begin{array}{l}\text { Desain } \\
\text { Sistem Sosial }\end{array}$ & $\begin{array}{l}\text { Revisi } \\
\text { Sistem Sosial }\end{array}$ \\
\hline $\begin{array}{l}\text { Fase I } \\
\text { Apersepsi sistem sosial ma- } \\
\text { syarakat sebagai pengantar } \\
\text { sekaligus menyampaikan } \\
\text { tujuan pembelajaran dan } \\
\text { memotivasi siswa. }\end{array}$ & $\begin{array}{l}\text { Fase I } \\
\text { Menyampaikan tujuan, } \\
\text { memotivasi siswa, dan } \\
\text { apersepsi sistem sosial } \\
\text { masyarakat. }\end{array}$ & $\begin{array}{l}\text { Bekerja sama } \\
\text { menyelesaikan masalah } \\
\text { antara: siswa-siswa, } \\
\text { guru-siswa, dan } \\
\text { kelompok }\end{array}$ & $\begin{array}{l}\text { Bekerja sama menyele- } \\
\text { saikan masalah antara: } \\
\text { siswa-siswa dan guru- } \\
\text { siswa }\end{array}$ \\
\hline $\begin{array}{l}\text { Fase II } \\
\text { Representasi pembelajaran } \\
\text { melalui pola interaksi sosial } \\
\text { masyarakat. }\end{array}$ & $\begin{array}{l}\text { Fase II } \\
\text { Representasi pembelajaran } \\
\text { melalui pola interaksi } \\
\text { sosial masyarakat dan } \\
\text { pengorganisasian siswa } \\
\text { kedalam kelompok }\end{array}$ & $\begin{array}{l}\text { Kebebasan } \\
\text { mengemukakan } \\
\text { pendapat }\end{array}$ & $\begin{array}{l}\text { Kebebasan } \\
\text { mengemukakan } \\
\text { pendapat secara klasikal } \\
\text { terbimbing }\end{array}$ \\
\hline $\begin{array}{l}\text { Fase III } \\
\text { Pengorganisasian siswa } \\
\text { kedalam kelompok. }\end{array}$ & $\begin{array}{l}\text { Fase III } \\
\text { Presentase dan } \\
\text { pengembangan hasil kerja. }\end{array}$ & $\begin{array}{l}\text { Kerjasama siswa- } \\
\text { siswa, guru-siswa, } \\
\text { antara kelompok } \\
\text { terlaksana selama } \\
\text { pembelajaran }\end{array}$ & $\begin{array}{l}\text { Kerjasama siswa-siswa } \\
\text { dan guru-siswa } \\
\text { terlaksana selama } \\
\text { pembelajaran }\end{array}$ \\
\hline $\begin{array}{l}\text { Fase IV } \\
\text { Presentase dan pengembangan } \\
\text { hasil kerja. }\end{array}$ & $\begin{array}{l}\text { Fase IV } \\
\text { Penemuan objek } \\
\text { matematika disertai } \\
\text { pengembangan skemata } \\
\text { baru. }\end{array}$ & $\begin{array}{l}\text { Interaksi sosial kultural, } \\
\text { siswa tidak diizinkan } \\
\text { berbahasa daerah dalam } \\
\text { pembelajaran. }\end{array}$ & $\begin{array}{l}\text { Interaksi sosial kultural, } \\
\text { siswa diizinkan berbahasa } \\
\text { daerah dalam } \\
\text { pembelajaran. }\end{array}$ \\
\hline $\begin{array}{l}\text { Fase IV } \\
\text { Presentase dan pengembangan } \\
\text { hasil kerja. }\end{array}$ & $\begin{array}{l}\text { Fase IV } \\
\text { Penemuan objek } \\
\text { matematika disertai } \\
\text { pengembangan skemata } \\
\text { baru. }\end{array}$ & $\begin{array}{l}\text { Interaksi sosial kultural, } \\
\text { siswa tidak diizinkan } \\
\text { berbahasa daerah dalam } \\
\text { pembelajaran. }\end{array}$ & $\begin{array}{l}\text { Interaksi sosial kultural, } \\
\text { siswa diizinkan berbahasa } \\
\text { daerah dalam } \\
\text { pembelajaran. }\end{array}$ \\
\hline $\begin{array}{l}\text { Fase VI } \\
\text { Refleksi hasil pembelajaran } \\
\text { disertai penghargaan. }\end{array}$ & & & \\
\hline
\end{tabular}

Tabel 3: Fase-fase Pembelajaran

\begin{tabular}{|c|c|}
\hline Kegiatan Guru & Kegiatan Siswa \\
\hline \multicolumn{2}{|l|}{$\begin{array}{l}\text { Fase I: Menyampaikan tujuan, memotivasi siswa, dan apersep- } \\
\text { si sistem sosial masyarakat }\end{array}$} \\
\hline $\begin{array}{l}\text { Guru membuka pelajaran dengan menyampaikan kompetensi } \\
\text { dasar }(\mathrm{KD}) \text {, dan indikator kepada siswa }\end{array}$ & $\begin{array}{l}\text { Mendengar penjelasan guru dan berta- } \\
\text { nya bila belum jelas tentang }\end{array}$ \\
\hline $\begin{array}{l}\text { KD : Menggunakan bentuk aljabar dalam pemecahan masalah } \\
\text { aritmetika sosial yang sederhana. }\end{array}$ & kompetensi dasar dan indikator \\
\hline $\begin{array}{l}\text { Indikator: menuliskan pengertian diskon, bruto, tara, dan neto } \\
\text { dengan kata-kata sendiri menuliskan hubungan antara bruto, } \\
\text { tara, dan neto dengan kata-kata sendiri. }\end{array}$ & \\
\hline
\end{tabular}


Memotivasi siswa dengan menguraikan pentingnya mempelajari materi ajar dan menjelaskan pelaksanaan pembelajaran (menjelaskan pola interaksi sistem sosial masyarakat) kepada siswa
Mendengar penjelasan guru dan bertanya bila belum jelas
Contoh: Anak-anak!!! KD dan indikator yang Bapak sampaikan tadi, merupakan hal yang penting untuk dipahami karena sering anak-anakku jumpai bila berbelanja (jual beli).

Karena itu, untuk memahami materi ini, Bapak nanti akan bagikan buku, kemudian didiskusikan dengan teman kelompoknya.

Dalam belajar dan berdiskusi, anak-anakku harus tetap mengingat falsafah orang tua (falsafah Bugis-Makassar: sipakatau, pacce, abbulosibatang, siri' dsb.)

Mengingatkan kembali materi prasyarat/ sebelumnya dan apersepsi sistem sosial masyarakat dalam pembelajaran/ memecahkan masalah, sehingga siswa memandang matematika sebagai hasil konstruksi sosial

Contoh: Guru mengingatkan materi sebelumnya tentang: harga pembelian, harga penjualan, untung, dan rugi dengan mengajukan pertanyaan kepada siswa. Namun sebelumnya diberikan cerita jual beli yang sering terjadi di masyarakat yang biasa dilakukan oleh siswa dengan menyampaiakan tatakrama dan sopan santun dalam proses jual beli. Dalam hal ini guru juga mengaitkan matematika dengan konstruksi sosial, seperti pantang menyerah, jujur, berprinsip, konsisten, dalam jual beli (bekerja).

Fase II: Representasi pembelajaran melalui pola interaksi sosial masyarakat dan pengorganisasian siswa ke dalam kelompok

Mengorganisir pengelompokan siswa dengan memperhatikan sistem sosial masyarakat (sipakatau, pacce, abbulosi-batang)

Contoh: Guru membantu siswa membentuk kelompok. Anak-anakku semua!!! Sebelum membentuk kelompok perlu Bapak ingatkan bahwa anggota kelompok nanti harus selalu saling sipakatau, pacce, dan abbulosibatang sesama kelompok dalam bekerja.

Mengarahkan siswa membaca bahan ajar dan memahami contoh permasalahan yang ada di buku siswa sambil berdiskusi dengan kelompoknya.
Mendengar penjelasan guru tentang materi prasyarat dan sistem sosial masyarakat dalam pembelajaran/ memecahkan masalah, dan bertanya bila belum jelas

Membentuk kelompok

Membaca bahan ajar di buku siswa

\footnotetext{
Kegiatan Guru

Mendorong/mengarahkan siswa bekerja sama dalam menyelesaikan masalah di LKS, sambil memberikan scaffolding pada individu atau kelompok yang mengalami kesulitan

Contoh: Anak-anak, Bapak lihat kalian kurang semangat, ayo pasti bisa! (guru berkeliling di kelas mengawasi siswa bekerja sambil memberikan bantuan seperlunya jika ada yang membutuhkan)

Mengingatkan agar siswa saling sipakatau dan pacce/pesse terhadap teman yang memerlukan bantuan

Contoh: Siapa yang sudah paham agar membantu temannya, sedang yang belum paham jangan malu bertanya.
}

\section{Kegiatan Siswa \\ Bekerja sama dalam menyelesaikan masalah dan menuliskan penyelesai- annya di LKS, namun bila ada yang belum jelas menanya-kan pada guru (baik individu atau kelompok) dan memperhatikan penjelasan guru}


Fase III: Presentase dan pengembangan hasil kerja.

Memandu siswa membuat kesimpulan materi ajar dan memberi penghargaan terhadap hasil kerja idividu atau kelompok dengan tetap memperhatikan sistem sosial masyarakat.
Salah seorang anggota kelompok mempersentasikan hasil penyelesaiannya di kelas
Misal nilai (sipakatau, pacce, abbulosibatang, dsb.) melalui persentase kelas

Contoh: Anak-anak, sekarang kerja kelompoknya sudah selesai, selanjutnya kita persentasikan kerja kelompoknya. Untuk itu Bapak meminta satu orang setiap kelompok untuk menjelaskan di papan. Ayo silakan tunjuk tangan kelompok yang akan tampil duluan! (selain itu guru dapat menunjuk langsung kelompok yang tampil duluan sesuai kondisi saat itu).

Memberi kesempatan kelompok lain mengkritisi/menanggapi hasil kerja kelompok penyaji sambil menguji pemahaman siswa.

Contoh: Anak-anak! Perhatikan jawaban temanmu di atas. Sekarang kelompok lain saya beri kesempatan memberikan masukan atau bertanya jika ada yang belum dimengerti. Namun, Bapak perlu ingatkan bahwa dalam menanggapi hasil kerja temanmu harus tetap menghargai pendapat teman, memegang prinsip berprestasi, saling membantu, kebersamaan, dan kesetiaan.

Mengontrol jalannya diskusi yang berpedoman pada sistem sosial masyarakat, sambil mendorong keterbukaan, proses demokrasi dalam berdiskusi.

Fase IV: Penemuan objek matematika disertai pengembangan skemata baru.

Mengarahkan siswa membangun konsep dan prinsip secara ilmiah.

Contoh: Anak-anak! Mari secara bersama-sama kita cermati pekerjaan temanmu di papan. Dengan memberi penjelasan singkat sambil menjelaskan makna konsep dan prinsip tentang materi yang dibahas.

Menguji pemahaman siswa atas konsep yang ditemukan melalui pengajuan contoh dan bukan contoh.

(Guru meminta siswa menyebutkan contoh dan non-contoh tentang konsep dan prinsip materi jual beli)
Menyajikan hasil kerja kelompok; menjawab/memberi tanggapan tentang hasil penyelesaian masalah

Memperhatikan, berdiskusi, dan menjawab/memberi tanggapan tentang hasil penyelesaian masalah

Mengkaji ulang hasil pemecahan masalah yang telah diselesaikan baik secara individu maupun secara kelompok

Menyelesaikan soal-soal yang diberikan baik secara individu maupun secara berkelompok

\begin{tabular}{l}
\hline Kegiatan Guru \\
\hline Membantu siswa mendefinisikan dan mengorganisasikan \\
tugas-tugas belajar yang berkaitan dengan masalah
\end{tabular}

Fase V: Refleksi hasil pembelajaran disertai penghargaan. Mengkaji ulang materi pembelajaran/hasil pemecahan masalah (Refleksi hasil pembelajaran) disertai pemberian penghargaan kepada individu/kelompok yang berprestasi (Guru menjelaskan materi yang menurut hasil pengamatannya belum dipahami oleh siswa sambil memberikan pertanyaan kepada siswa. Selain itu, guru memberi penghargaan kepada

\section{Kegiatan Siswa}

Baik secara berkelompok atau secara individu melakukan pengorganisasian tugas-tugas belajar yang telah ia lakukan

Menjawab pertanyaan guru dan bertanya bila ada permasalahan belum ia pahami Membuat catatan tentang hal-hal yang dianggap penting sebagai rangkuman hasil pembelajaran 
individu/kelompok berprestasi)

Mengevaluasi materi akademik siswa melalui pembuatan peta konsep/materi disertai pemberian kuis.

(Guru mengajukan pertanyaan tentang materi pembelajaran berdasarkan peta konsep/materi dalam pembelajaran)

Memberi tugas PR
Menjawab pertanyaan guru secara lisan dan menyelesaikan soal-soal yang diberikan

Mencatat tugas-tugas yang diberikan baik secara individu atau kelompok

\section{Penerapan Sistem Sosial}

Sistem sosial menyatakan peran dan hubungan antara siswa \& guru yang berlaku dalam proses pembelajaran. Peran dan hubungan antara siswa-siswa, siswa-guru atau sebaliknya menerapkan sistem sosial masyarakat etnis Bugis-Makassar, yaitu: reso, siri, sipakatau, sipakainge, semangat persaingan dan dorongan berprestasi, menggunakan waktu yang tepat, kepribadian dan watak, lempu atau jujur, tegas dan teguh dalam pendirian, berani (tidak penakut), kepatutan (moderat) atau rendah hati, dan motivasi. Pola interaksi edukatif dilakukan pada saat diskusi kelompok. Pada saat itu, mereka berkesempatan berkolaborasi, saling mempertahankan pendapat, saling bertanya, saling membantu, menanggapi, dan membuat kesepakatan-kesepakatan untuk menyelesaikan masalah matematika yang mereka hadapi. Pada saat inilah sistem sosial masyarakat ditanamkan, seperti pada saat diskusi harus menjunjung tinggi nilai sipakatau dan sipakainge.

\section{Penerapan Prinsip Reaksi}

Prinsip reaksi berkaitan dengan bagaimana cara guru memperhatikan dan memperlakukan siswa, termasuk bagaimana guru memberikan respon terhadap pertanyaan, jawaban, tanggapan atau apa yang dilakukan siswa. Perilaku guru yang diharapkan dalam pelaksanaan pembelajaran seperti berikut. Pertama, menarik perhatian siswa agar memperhatikan penjelasan atau informasi yang disampaikan. Kedua, selama siswa bekerja secara individu atau kelompok, guru berkeliling untuk mengamati tingkah laku siswa agar tidak terjadi tingkah-laku yang tidak relevan dengan kegiatan pembelajaran, dan mengontrol jalannya diskusi, meliputi: memberi kesempatan pada siswa untuk mengungkapkan ide-idenya dan merekam perilaku siswa yang terkait dengan keterampilan sosialnya selama diskusi berlangsung. Ketiga, memberi bantuan/bimbingan kepada siswa atau kelompok yang mengalami kesulitan menyelesaikan masalah. Bimbingan yang dimaksud berupa scaffolding agar siswa tetap mengkonstruksi pengetahuannya sendiri dalam proses pemecahan masalah yang diberikan.

\section{Temuan Penelitian}

Ketercapaian tujuan penelitian, yaitu sejauh mana tujuan yang diharapkan telah tercapai. Ketercapaian ini dikaitkan dengan kevalidan, kepraktisan, dan keefektifan model pembelajaran. Temuan khusus yang akan diungkapkan, yaitu temuan yang diperoleh selama proses uji coba model pembelajaran, khususnya yang terkait dengan kondisi siswa.

Pertama, proses pengujian awal (validasi) model dinyatakan valid ditinjau dari keseluruhan aspek/komponen model, namun demikian teoriteori belajar yang digunakan dianggap belum cukup untuk mendukung model. Beberapa validator menyarankan bahwa model pembelajaran ini harus tetap didasari oleh teori konstruktivisme tanpa mengabaikan teori behaviorisme karena model ini dapat menjembatani kedua teori tersebut.

Kedua, secara teoretis, berdasarkan hasil penilaian ahli model ini dinyatakan layak diterapkan di kelas. Secara empiris, berdasarkan hasil uji coba model ini memenuhi kriteria kepraktisan dankeefektifan.

Ketiga, temuan lain yang dianggap penting dalam penelitian ini adalah sebagai berikut. (1) Pada uji coba I, ada 6 dari 22 siswa yang memperoleh skor penguasaan bahan ajar kurang dari $60 \%$ (belum kompeten menurut standar kompetensi minimal (SKBM) matematika dari sekolah tempat uji coba), dan hanya terdapat 3 orang siswa yang memperoleh skor lebih dari 
$85 \%$ (penguasaan sangat tinggi). Pada uji coba II ada 2 dari 25 siswa yang memperoleh skor penguasaan bahan ajar kurang dari $60 \%$ (belum kompeten menurut standar kompetensi minimal (SKBM) matematika dari sekolah tempat uji coba), dan hanya terdapat 4 orang siswa yang memperoleh skor lebih dari $85 \%$ (penguasaan sangat tinggi). Aspek respon siswa terhadap pembelajaran pada uji coba I dan II, semua siswa merespon positif. (2) Salah satu hasil yang diperoleh dalam penelitian ini adalah pembelajaran dengan model berdampak pada pencapaian ketuntasan belajar (minimal 85\% siswa mecapai nilai standar ketuntasan belajar minimal (SKBM) yang ditetapkan oleh sekolah tempat uji coba, yaitu 6,0 ke atas). Hasil ini menunjukkan bahwa apabila, menggunakan model pembelajaran dengan mengoptimalkan aktivitas dan kreativitas siswa, serta menyenangkan, akan berimplikasi positif terhadap kesuksesan belajar seseorang.

\section{PENUTUP}

Model pembelajaran matematika yang memanfaatkan sistem sosial masyarakat memenuhi kriteria valid, praktis, dan efektif. Model pembelajaran ini mencakup komponen: sintaks, prinsip reaksi, sistem sosial, sistem pendukung, dan dampak instruksional \& pengiring. Produk penelitian adalah buku model pembelajaran dan perangkat pendukung pembelajaran, yaitu: rencana pelaksanaan pembelajaran, buku siswa, lembar kegiatan siswa, dan tes hasil belajar.

\section{UCAPAN TERIMA KASIH}

Segala puji dan syukur penulis panjatkan kepada Allah SWT. karena dengan kehendak dan izin-Nya serta rahmat dan hidayahNya, penelitian ini dapat diselesaikan. Berkenaan dengan itu, sepantasnya penulis menyampaikan penghargaan dan ucapan terima kasih kepada: (1) Bapak Direktur DP2M Dikti yang telah meberikan dana melalui penelitian Hibah Bersaing multi-years; (2) Bapak Pimpinan UNM Makassar atas kesempatan yang diberikan kepada kami untuk melaksanakan penelitian ini; dan (3) Pengelola Jurnal Ilmiah Cakrawala Pendidikan Universitas Negeri Yogyakarta yang telah menerbitkan hasil penelitian ini.

\section{DAFTAR PUSTAKA}

Bloom, Madaus \& Hasting. 1981. Methods Grading in Summative Evaluation. New York: McGraw-Hill.

Davis, Robert, B. 1990. "Learning Discovery and Constructivism". Rutgers University: Journal of Teacher Education Mathematics, Vol. 3, No 23.

Depdiknas. 2006. Standar Isi untuk Satuan Pendidikan Dasar dan Menengah. http:/www.puskur.net/.

Depdiknas. 2003. Undang-Undang RI No. 20 tentang Sisdiknas. http:/www. dikna.org/.

Dick, Walter., \& Carey, Lou., Carey, James O. 2005. The Systematic Design of Instruction (7th ed). New York: Longman.

Djamarah, Syaif Bahri. 2000. Guru dan Anak Didik dalam Interaksi Edukatif. Jakarta Rineka Cipta.

Joyce, B., Weil, M., \& Calhoun, E. 2004. Models of Teaching. Boston: Pearson Education, Inc.

Nieveen, Nienke., 1999. "Prototyping to Reach Product Quality". In Jan Van den Akker, R.M. Branch, K. Gustafson, N. Nieveen \& Tj. Plomp (Eds). Design Approaches and Tools in Education and Training ( $p p$ 125 - 135). Nederlands: Kluwer Academic Publishers.

Plomp, Tjeerd., 2007. "An Introduction to Educational Design Research" Proceedings of the seminar conducted at the East China Normal University, Shanghai (PR China), November 23-26, 2007.

Soedjadi. R., 2000. Kiat pendidikan matematika di Indonesia. Jakarta: Dirjen Dikti Depdikbud. 